Research Article

\title{
THOROUGH ANALYSIS OF COMBUSTION AND EMISSIONS OF POWER GENERATOR DIESEL ENGINE AT HIGH IDLING OPERATIONS FUELED WITH LOW PERCENTAGE OF DIFFERENT BIODIESEL BLENDS
}

\author{
Selman AYDIN ${ }^{l}$
}

\begin{abstract}
In this study, the ultimate aim is to provide objective scientific proof to promote biodiesel blends in constant areas (official institutions, hospital, school, etc.) as a renewable fuel. For that, biodiesel obtained from animal, vegetable and microalgae oil by a method of transesterification and these biodiesels have been prepared by $10 \%$ blended with diesel fuel and has been named respectively as AB10, VB10 and MB10. The biodiesel blends and reference diesel fuel (ULSD) have compared with by obtained combustion and emission values in a diesel engine generator system under cold start, loadless and high idling constant engine speed of 1500 rpm. Experimental results showed that using biodiesel blends in diesel engine generator system had almost parallel cylinder gas pressure (CGP), cumulative heat release $(C H R)$, heat release rate (HRR), knock density (KD) and mean gas temperature (MGT) compared to ULSD fuel operation in this research diesel engine. In addition, $\mathrm{CO}, \mathrm{NO} \mathrm{O}_{x}$ and $\mathrm{HC}$ emissions decreased, $\mathrm{CO}_{2}$ increased compared to ULSD fuel at same experimental conditions.
\end{abstract}

Keywords: Cold Start, Loadless, Power Generator Diesel Engine; Biodiesel, High Idling, Combustion

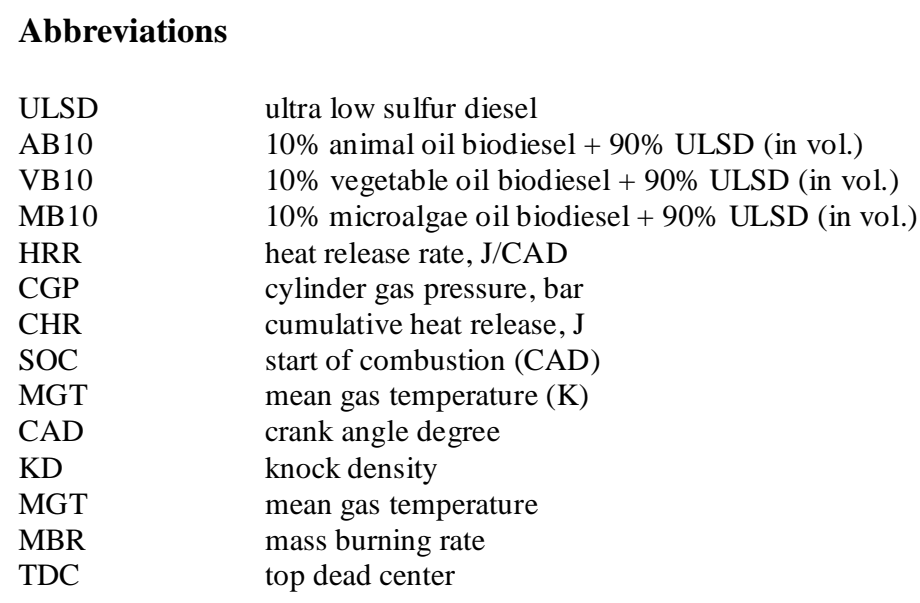

1 Department of Automotive Engineering, Faculty of Technology, University of Batman, 72060, Batman, Turkey (aydnselman@gmail.com) (D) https://orcid.org/0000-0001-9685-9853 


\section{Introduction}

Continuous depletion of fossil fuels, rising fossil-fuel prices, carbon prices, and the quest for cleaner environment for low carbon fuel these are the reasons why researchers are searching for fossil-fuel alternatives. Clean energy, non-flammable, environmentally friendly and non-toxic are some of the reasons that make biodiesel an acceptable choice for fossil-fuel substitution in the near future [1]. Biodiesel is fast becoming the best option for replacing diesel fuel among many renewable fuels. This is due to their potential for satiating energy demand, rising global warming and greenhouse gasses $[2,7]$. In addition, biodiesel is distinct from traditional diesel fuel; in any case, it does not contain any kind of undesirable fixations, such as sulphur and polycyclic aromatics. Biodiesel can be used instead of diesel fuel without making any outstanding changes to the engine fuel system components $[6,3]$. Microalgae are stated to be the alternative source of biomass feedstock for biodiesel that can meet the transport sector's global demand due to superior productivity of biomass and high oil content. Microalgae are capable of producing double biomass in about two days [4,5,10]. For current fuel systems, high engine efficiency should be taken from the biofuel without causing any damage to engine components [8].

Microalgae fuels in a research diesel engine and investigated the factors affecting the in cylinder gas pressure values and maximum in-cylinder pressure change. In this study used diesel fuel, crude microalgae oil and biodiesel based on the results of their study, microalgae oil and biodiesel reduced the performance parameters of engine, as there is an increase on the noise of engine owing to knock density [9]. In a separate analysis by the same team [11], it was demonstrated that the start of injection timings of biodiesel fuels resulted in earlier timings in comparison with diesel fuel owing to its high density and kinematic viscosity.

The purpose in this study of used animal biodiesel, vegetable biodiesel and microalgae biodiesel, which blended ultra-low sulfur diesel fuel (ULSD), was to investigate the possibility and usability of 10 percent biodiesel in a diesel engine generator power at cold start and loadless conditions. The European Union's Renewable Energy Directive, which promotes the use of renewable energy, mandates that at least $10 \%$ of the energy resources used in the transportation industry will come from renewable energy sources. Inspired by this idea; three biodiesel blends and ULSD are evaluated and compared, under cold start and loadless conditions of research engine to identify combustion parameters. The ultimate goal is to provide reliable scientific evidence to support biodiesel blending as a renewable fuel in constant areas (official organizations, hospital, education, etc.). Comprehensive experiments have been carried out to evaluate the change in combustion parameters when running the engine with test fuels under cold start, loadless conditions and high idling $1500 \mathrm{rpm}$ in a power generator diesel engine. In addition, under cold start, high idling and unloaded operating conditions, no detailed study has been found in literature on the combustion parameters of AB10, VB10 and MB10 biodiesel blends. 


\section{Material and Experimental Methods}

\subsection{Experimental setup and installations}

In this study, the animal oil biodiesel ( $\mathrm{AB}$ ) was derived from beef bone marrow by transesterification for the experimental study at the chemical plant in Istanbul (TR), the vegetable oil biodiesel (VB) produced from safflower/canola oil blend was provided from a commercial facility in Kocaeli (TR), and ULSD was purchased in a commercial station in Batman (TR). The aim of various source of biodiesel with ULSD blends was to investigate the possibility and usability in a diesel engine powered generator under cold start, high idling and unloaded operating conditions. So that, experiment fuels were prepared by blending 90\% ULSD + 10\% animal fat oil biodiesel (AB10), 90\% ULSD + 10\% safflower/canola biodiesel (VB10) and 90\% ULSD + 10\% microalga oil biodiesel (MB10). Together with the $10 \%$ blends, it produces the best engine performance and can minimize exhaust emissions in comparison with diesel fuel, except $\mathrm{NO}_{\mathrm{x}}$ [12]. Thus, biodiesel blend ratios were chosen as $10 \%$. Tab. 1 presents some of the significant chemical and physical characteristics of this fuels.

Table 1. Some of physical and chemical characteristics of ULSD, AB 10, VB10 and MB10 fuels.

\begin{tabular}{llllllc}
\hline Parameter / Test fuels & ULSD & AB10 & VB10 & MB10 & EN 14214 & ASTM D6751 \\
\hline $\begin{array}{l}\text { Lower colorific value, } \\
(\mathrm{kJ} / \mathrm{kg})\end{array}$ & 42550 & 40250 & 41580 & 41530 & - & - \\
Viscosity, $40{ }^{\circ} \mathrm{C}\left(\mathrm{mm}^{2} / \mathrm{s}\right)$ & 2.959 & 3.014 & 3.896 & 3.968 & $3.5-5$ & $1.6-6$ \\
Diesel index & 50.5 & 52.4 & 53.8 & 51.4 & $51 \mathrm{~min}$ & $47 \mathrm{~min}$ \\
\hline
\end{tabular}

The experimental investigation has been carried out using every one of the ULSD, AB10, VB10 and MB10 experiment fuels in a diesel engine power generator working at cold start, high idling speed of $1500 \mathrm{rpm}$ and loadless. The experimental configuration schematic diagram has viewed in Fig. 1. The aim of various source of biodiesel with ULSD blends was to investigate the possibility and usability in a diesel engine powered generator with high idling operations.

Table 2. Specifications of engine diesel powered electric generator

\begin{tabular}{ll}
\hline Engine parameter & Specification \\
\hline Output power & $18 \mathrm{~kW}$ \\
Cooling system & Water cooling \\
system of Intake & Naturally aspirates \\
Model & $4 \mathrm{DW} 81-23 \mathrm{D}$ \\
Bore x stroke $(\mathrm{mm})$ & $85 \times 100$ \\
Displacement $\left(\mathrm{cm}^{3}\right)$ & 2400 \\
Cylinders & 4 \\
System of combustion & Direct injection \\
Compression ratio & $17: 1$ \\
Injector nozzles & 4 \\
Injection timing & $23^{\circ}$ BTDC \\
Injection pressure & 400 bar \\
\hline
\end{tabular}


Together with the $10 \%$ blends, it produces the best combustion and can minimize exhaust emissions in comparison with diesel fuel, except NOx. [12]. Thus, blends of biodiesel were chosen as 10\%. Tab. 1 presents some of the significant chemical and physical properties of test fuels.

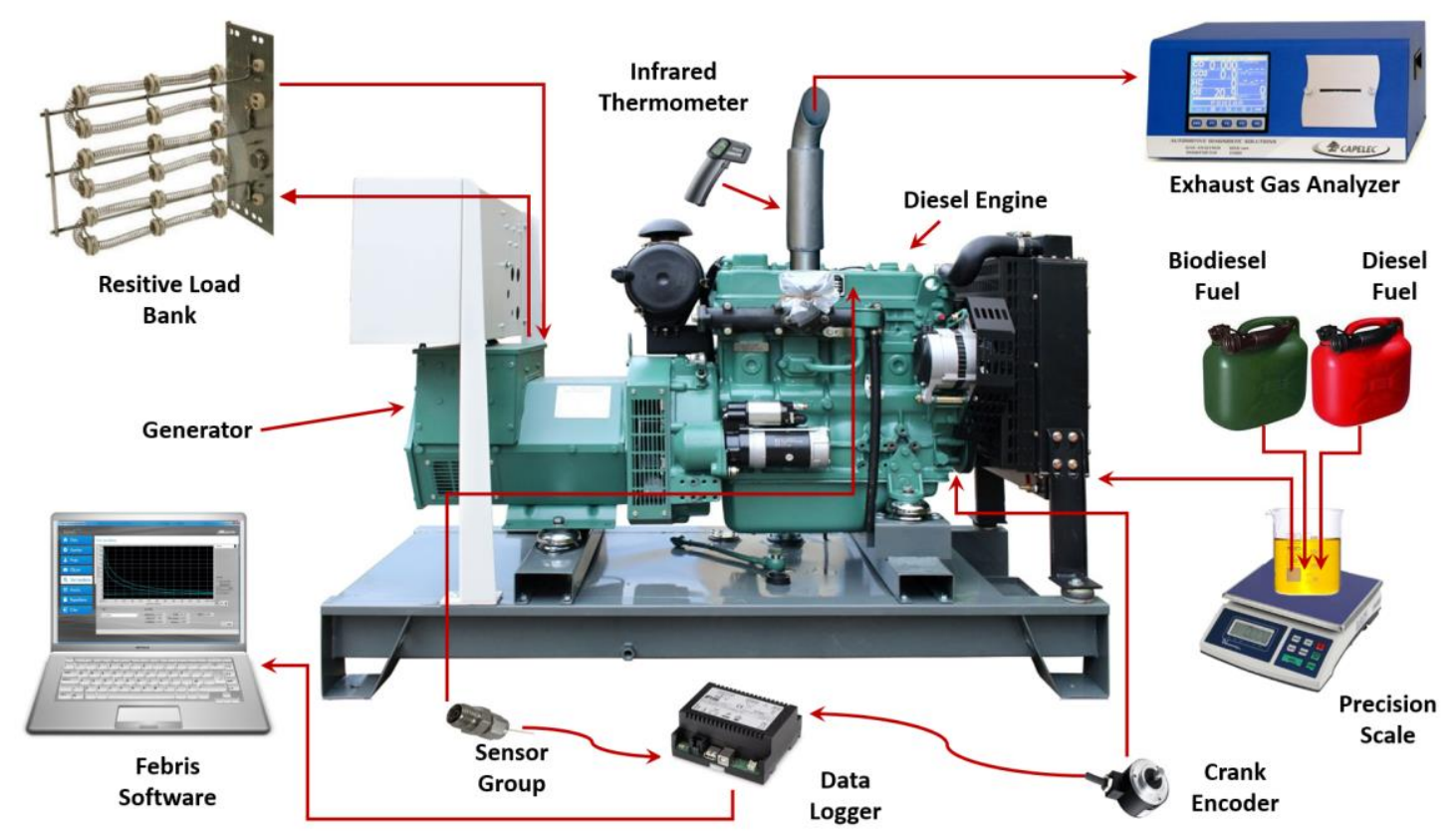

Figure 1. The view of overall experimental configuration

\subsection{Methods of Calculation}

The parameter of combustion values were obtained by a piezoelectric transducer mounted in the combustion chamber and analyzed by FEBRS combustion software, which allows data to be collected from the cylinder pressure sensor and crank encoder. The obtained and measured by this application is the volume of the cylinder, cylinder gas pressure (CGP), mean piston speed and piston acceleration versus CAD. The CGP was written down for each CAD of $1^{\circ}$ and mean of 100 cycles were utilized by the crank encoder. In this work, CGP and other combustion parameters were used to compute knock density (KD), heat release rate (HRR), mean gas temperature (MGT) and total heat release (CHR). By means of software, each CAD of $1^{\circ}$ and average of 100 cycles were established for all parameters by equations below:

$\dot{Q}=\frac{\gamma}{\gamma-1} P d V+\frac{1}{\gamma-1} V d P+Q_{w}$

The ratio of specific heats is given in Eq. (2) benefited with the mean gas temperature [13].

$\gamma=1.338-60 \times 10^{-5} T+10^{-8} T^{2}$

The cumulative heat release (CHR) was calculated in Eq. (3) [14]. 
$\int d Q=\int\left(\frac{\gamma}{\gamma-1}\right) p(d V)+\int\left(\frac{1}{(\gamma-1)}\right) V(d P)$

In heat transfer coefficient (HTC) was calculated by using the Eq. (4) [14].

$h=C_{0} V^{-0.06} p^{0.8} T^{-0.4}\left[c_{m}+1.4\right]^{0.8}$

The knock density (KD) was given in Eq. (5) and calculated from cylinder gas pressure and mentioned above parameters [15].

$d p(\theta)=\frac{\left[86\left(p_{i-4}-p_{i+4}\right)+142\left(p_{i+3}-p_{i-3}\right)+193\left(p_{i+2}-p_{i-2}\right)+126\left(p_{i+1}-p_{i-1}\right)\right]}{1188 d \theta}$

\section{Experimental Result and Discussion}

\subsection{Combustion results}

In this combustion results section, in cylinder gas pressure (CGP), heat release rate (HRR), knock density (KD), cumulative heat release (CHR) and other significant combustion characteristic depend on crank angle degree (CAD) of power generator diesel engine were examined for ULSD, AB10, VB10 and MB10 test fuels. It can be observed in the Fig. 2 that in CGP and HRR values increased as the experimental engine cold conditions and high idling operations. In order to prevent cyclical differences, the CGP used in the calculation were taken as the average of 100 cycles. The CGP values of loadless cases have occurred after top dead center (TDC). Maximum CGP was occurred at 50.415305 bar in the ULSD test fuel, taken as $9^{\circ}$ after TDC. Other hand, under identical experimental conditions, it occurred with 50.265965 bar pressure in AB10 fuel 8 CAD after TDC, with 52.018538 bar pressure in VB10 fuel 9 CAD after TDC and with 52.019738 bar pressure in MB10 fuel 8 CAD after TDC. When in CGP versus on CAD for all test fuels under cold start and loadless conditions were observed, it is seen that every cycle is almost different from each other. There are a many similar results reported in the literature [17-19]. The development of cyclic variations includes a variety of physical and chemical factors [16, 24, 27, 29].

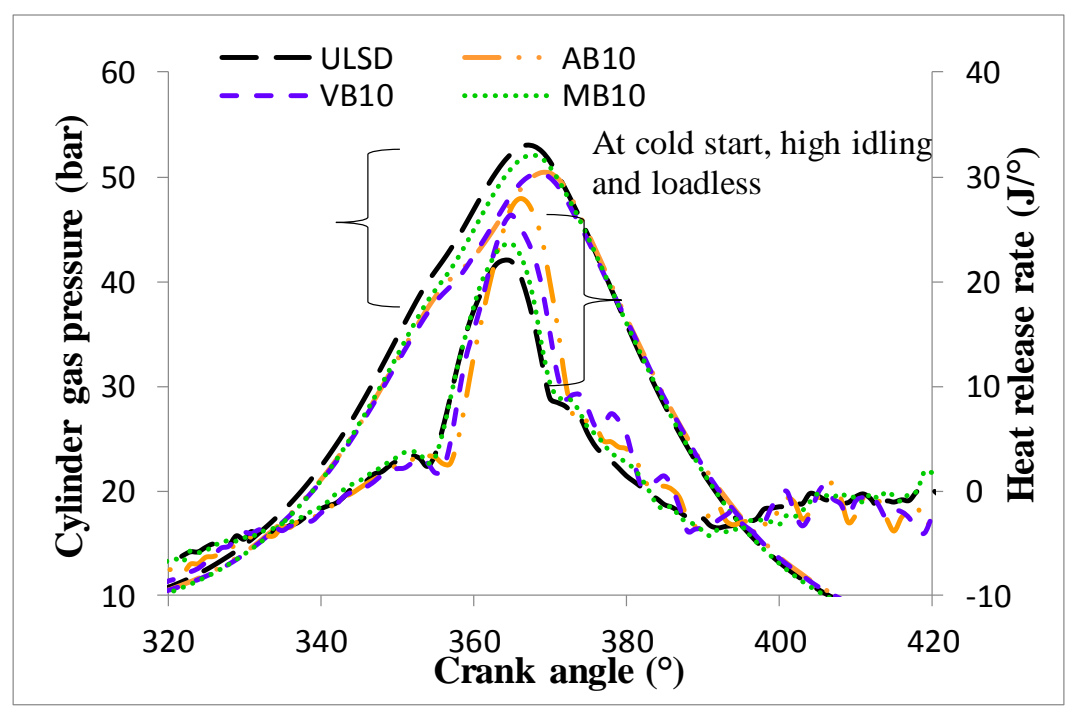

Figure 2. Changing of CGP and HRR curves with CAD at cold start, high idling and loadless conditions 
Maximum HRR values were obtained after TDC was between $359^{\circ}-365^{\circ}$ under cold start, loadless and high idling conditions were observed, it is seen in the Fig. 2. The most important parameters affecting the HRR of test fuels are; cetane number, density, viscosity, erasable internal temperature and thermal value. Cetane number, viscosity and density affect the ignition delays of fuels, and as the ignition delay increases, the rate of heat release increases [21-21]. Under cold start, high idling and loadless conditions, maximum HRR for ULSD was obtained as $22.00524 \mathrm{~J} / \mathrm{CAD}$ after $8^{\circ}$ from TDC. Moreover, under identical experimental conditions, maximum HRR for AB10 fuel was measured as $27.891084 \mathrm{~J} / \mathrm{CAD}$ after $10^{\circ} \mathrm{TDC}$, maximum HRR for VB10 occurred as $26.376701 \mathrm{~J} / \mathrm{CAD}$ after $9^{\circ}$ TDC and maximum HRR for MB10 occurred as 23.663952 J/CAD after $9^{\circ}$ TDC. Due to the load condition of the experimental engine, a significant difference was found when the HRR values were examined. The HRR values of test fuels were similar under identical experimental conditions. When the CGP and HRR curves were analyzed under same operating conditions, the combustion was delayed for VB10 blend. There are a many similar results reported in the literature [7, 19].

In Fig. 3 are properly inspected, it can be observed that the mean gas temperature (MGT) values have increased due to an increase in CGP at same experiment conditions. The MGT of VB10 fuel showed almost the same combustion behaviour with other fuels during the controlled combustion phase, while it was determined as the fuel that released the lowest temperature, which separates it from the other test fuels during the after combustion phase. The cold research engine is under high idling and loadless, the maximum MGT occurred $1390 \mathrm{~K}$ at $374 \mathrm{CAD}$ of engine with AB10 fuel. The MGT increases with the increasing inflammation depending on fuel composition of experimental fuel [23]. The knock density (KD) in diesel engines is that the fuel pumped into the cylinder does not instantly burn, but accumulates and burns unexpectedly, and the in-pressure increases. Thus, this is known as one of the reasons why diesel engines have a high noise level. When the Fig.3 are examined, no KD values has exceeded the acceptable value [22]. As can be observed that KD levels of all the test fuels were obtained at the appropriate values at cold start, high idling and loadless conditions.

Variation of in the mass burning rate (MBR) of ULSD, AB10, VB10 and MB10 test fuels at cold start, high idling and loadless conditions are given in Fig. 4. The MBR is a characteristic calculated from the CGP and volume change of the cylinder in the FEBRIS software based on LabVIEW. This parameter displays the amount of fuel burned at each crank angle over a cycle obtained from the mean of 100 cycles. For all the test blends, MBR values were identical to each other, but it has slight differences. Under same operating conditions VB10, MB10 and AOB10 test fuels have burnt earlier than the ULSD fuel. It is thought that the better evaporation end optimal blends of micro algae, vegetable oil biodiesel and animal fat biodiesel led to this propensity. Values of Heat transfer rate (HTR) depend on crank angel at same operating conditions are present in Fig. 4. As it can be observed in the figure, max. HTR of AB10 and VB10 at these experimental conditions compared to the ULSD and MB10 test fuels are higher. 


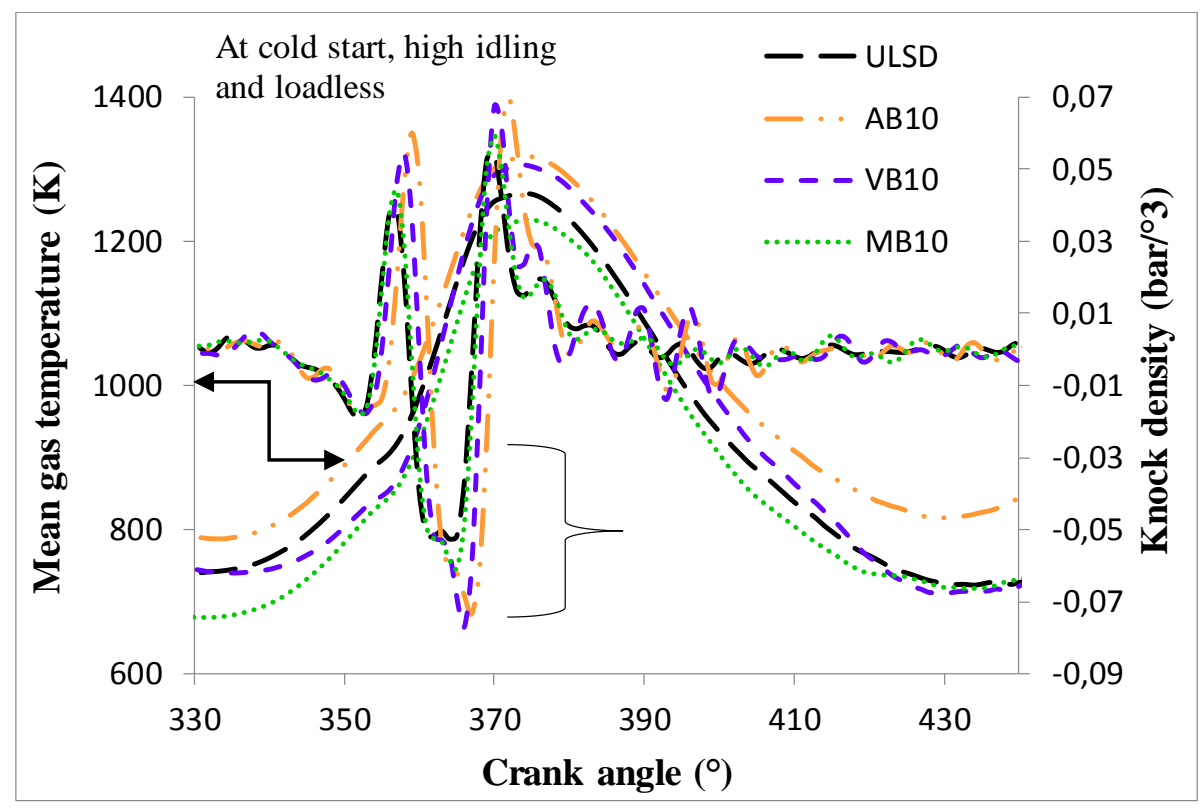

Figure 3. Changing of MGT and KD curves with CAD at cold start, high idling and loadless conditions

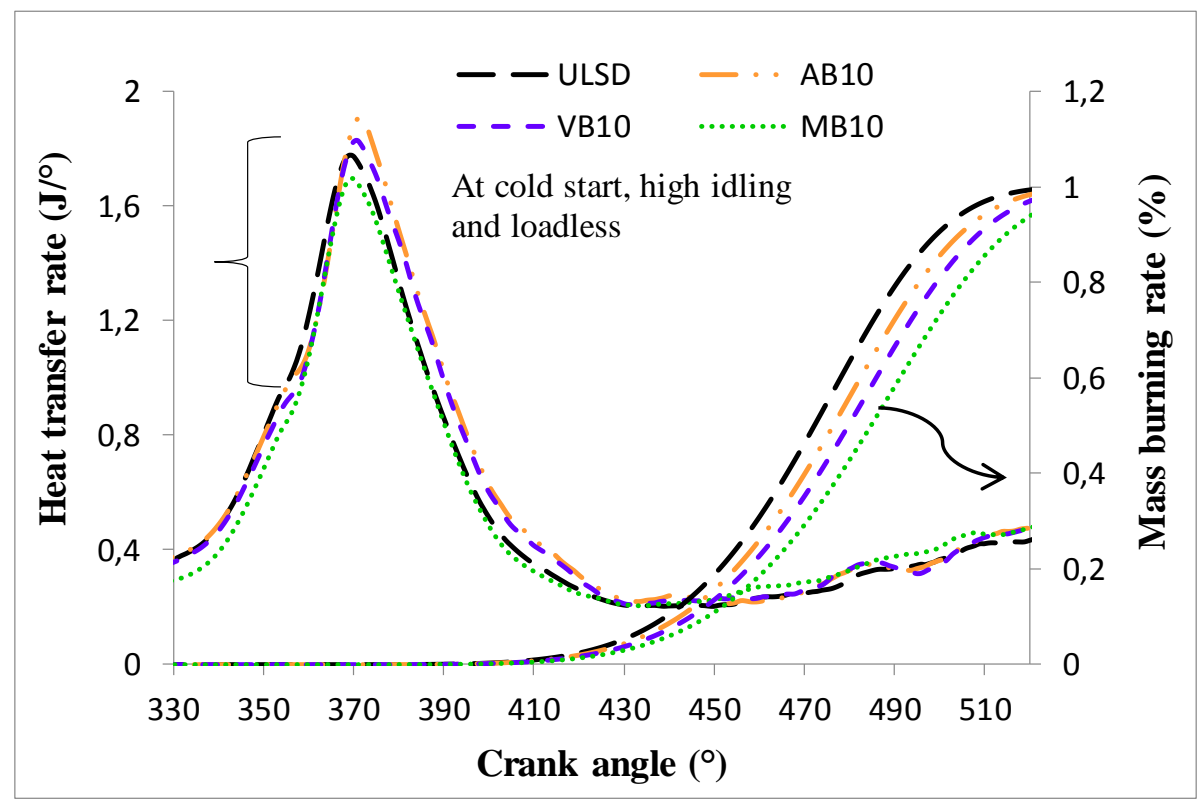

Figure 4. Changing of HTR and MBR curves with CAD at cold start, high idling and loadless conditions

Cumulative heat release (CHR) with depend on CAD for test fuels at cold start and loadless conditions are given in Fig. 5. CHR provides more information about the progress of test fuels combustion in experimental engine and also, CHR is net heat released from chemical energy of the experiment fuels. 
In same experimental conditions, maximum CHR values for test fuels were obtained after TDC. The lowest CHR values were obtained VB10 and AB10 at cold start, high idling and loadless conditions. Higher cetane number results in a lower ignition delay and lower fuel to be burned in the phase of premixed combustion. In case of look at Tab. 1, it is seen that the AB10 and VB10 have highest and ULSD have lowest cetane number. Therefore, as AB10 and VB10 fuels are predicted to have a shorter delay in ignition, and thus much more CHR value has been obtained. The higher CHR value of ULSD fuel is only related to the colorific value of the ULSD fuel. The changing of coefficient of heat transfer (CHT) curves with CAD for test fuels are given Fig. 5. The highest coefficient of heat transfer was obtained MB10 and ULSD fuels at cold start and loadless conditions of experimental engine. The increase in heat transfer coefficient is associated with the increase of MGT with engine loads and the cylinder gas velocity.

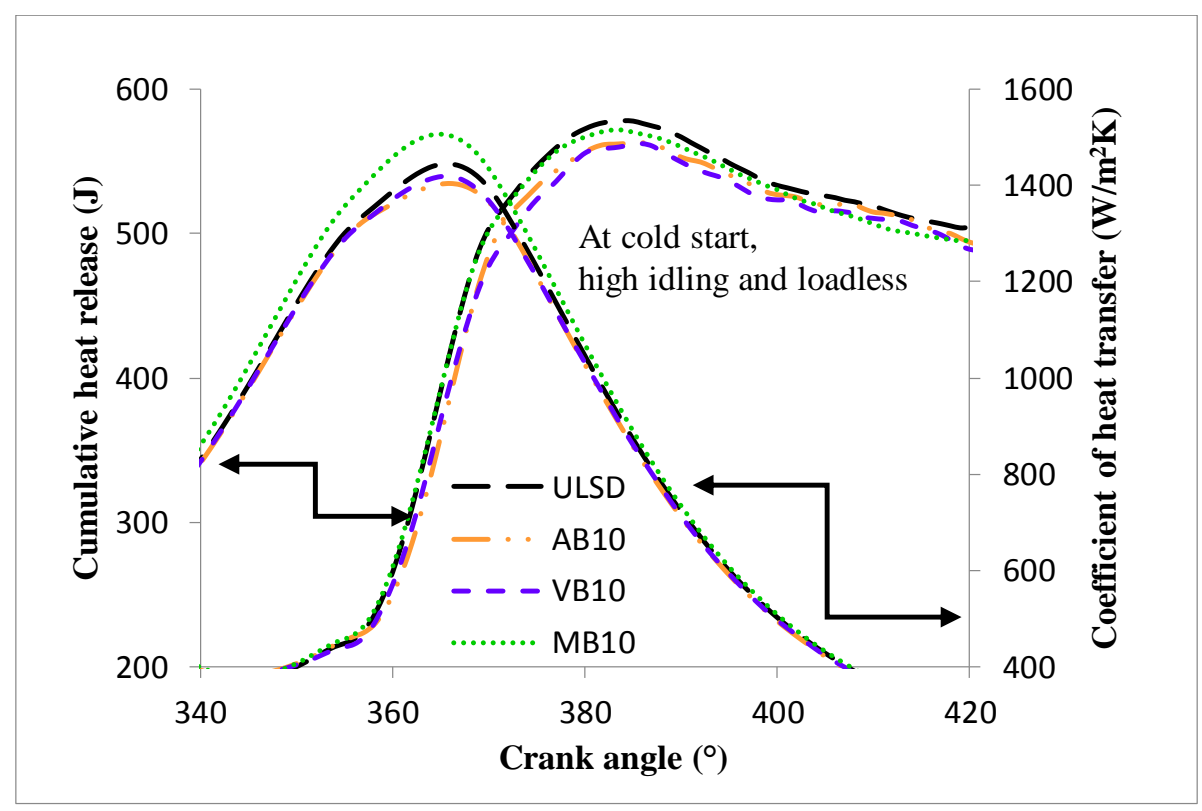

Figure 5. Changing of CHR and CHT curves with $\mathrm{CAD}$ at cold start, high idling and loadless conditions

\subsection{Emissions results}

Changing of $\mathrm{CO}, \mathrm{CO}_{2}, \mathrm{NO}_{\mathrm{x}}$ and $\mathrm{HC}$ emissions of test at cold start, high idling and loadless conditions are presented in Fig. 6A, 6B, 6C, 6D, respectively. In Fig. 6A, CO emissions of AB10, VB10 and MB10 blends were lower than ULSD into power generator diesel engine at cold start, high idling and loadless conditions. The reason may be due to the additional oxygen content in the biodiesel fuel [28]. $\mathrm{CO}_{2}$ emissions of $\mathrm{AB} 10, \mathrm{VB} 10$ and MB10 blends were higher than ULSD into power generator diesel engine at cold start, high idling and loadless conditions illustrated in Fig. 6B. 

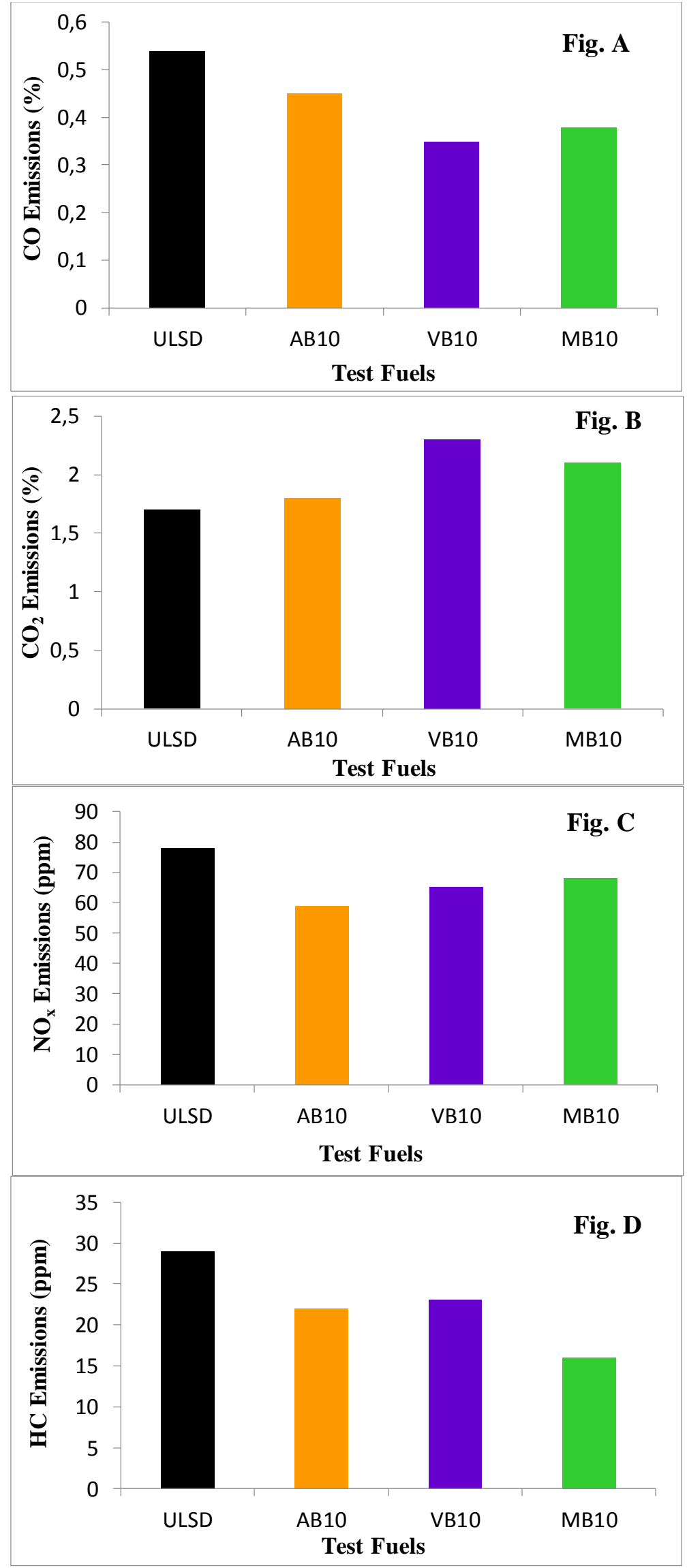

Figure 6. Changing of $\mathrm{CO}, \mathrm{CO}_{2}, \mathrm{NO}_{\mathrm{x}}$ and $\mathrm{HC}$ emissions of test fuels at cold start, high idling and loadless conditions 
The reason that may be owing to more efficient combustion of biodiesel blends at this operations condition. So the decline in the value of $\mathrm{CO}$ at loadless of experimental engine can be presented as evidence for increases of $\mathrm{CO}_{2}$ emissions at this conditions. $\mathrm{NO}_{\mathrm{x}}$ and $\mathrm{HC}$ emissions of test blends were lower than ULSD into power generator diesel engine at cold start, high idling and loadless conditions illustrated in Fig. 6C, 6D, respectively. The consequences of two major factors are produced the NOx emissions. Firstly, if the temperature of the combustion inside the cylinder is approximately higher than $1600{ }^{\circ} \mathrm{C}$, the nitrogen molecules begin to react with oxygen and as a result NOx is formed. Secondly, if the reaction time for the above-mentioned condition is reasonable, the amount of $\mathrm{NO}_{\mathrm{x}}$ emission will be emitted to the highest level [23].

\section{Conclusions}

The effect of AB10, VB10 and MB10 fuels on metrics of combustion in a diesel engine coupled with electrical generator under cold start, high idling and loadless conditions have investigated. This experimental study was carried out under cold start-loadless conditions and constant speed of the generator set. Based on the results obtained from the experiments the following conclusions were concluded:

* Parameters of combustion such as in-CGP, HRR, and CHR, MGT, MBR, and knock density were partly similar from ULSD fuel. It was identified that the curves were generally parallel to each other; and biodiesel-blended fuel combustion values showed behaviours close to the reference ULSD fuel. In addition, $\mathrm{CO}, \mathrm{NOx}$ and $\mathrm{HC}$ emissions decreased, $\mathrm{CO}_{2}$ emissions increased compared to ULSD fuel under cold start-loadless and high idling conditions of the power generator diesel engine.

* Because of the negative impact of fossil fuels on people and the environment, seeking alternative and cleaner energy sources has become crucial. Some of the alternative biodiesels were analyzed and tested in diesel engine power generator in this study. As the results show, AB10, VB10 and MB10 fuels performed better combustion measures than the ULSD reference. Considering that fossil fuels (gasoline, diesel fuel, oil, and natural gas) will end one day, although biodiesel fuels partially reduce engine performance, it can be used in construction machines requiring high torque.

\section{References}

[1] Sanjid, A., Masjuki, H.H., Kalam, M.A., Ashrafur Rahman, S.M., Abedin, M.J., Palash, S.M., Production of palm and jatropha based biodiesel and investigation of palm-jatropha combined blend properties, performance, exhaust emission and noise in an unmodified diesel engine, Journal of Cleaner Production, 65 (2014), 295-303. 
[2] Shahabuddin, M., Liaquat, A.M., Masjuki, H.H., Kalam, M.A., Mofijur, M., Ignition delay, combustion and emission characteristics of diesel engine fueled with biodiesel, Renew. Sustain. Energy Rev. 21(2013), 623-632.

[3] Singh, S.P., Singh, D., Biodiesel production through the use of different sources and characterization of oils and their esters as the substitute of diesel: a review, Renew. Sustain. Energy Rev. 14(2010), 200-216.

[4] Dassey, A.J., Hall, S.G., Theegala, C.S., An analysis of energy consumption for algal biodiesel production: comparing the literature with current estimates, Algal Res. 4(2014), 89-95.

[5] Ahmad, A.L., Yasin, N.H.M., Derek, C.J.C., Lim, J.K. Microalgae as a sustainable energy source for biodiesel production: a review, Renew. Sustain. Energy Rev. 15 (2011), 584-593.

[6] Efe, Ş., Ceviz, M.A., Temur, H., Comparative engine characteristics of biodiesels from hazelnut, corn, soybean, canola and sunflower oils on DI diesel engine, Renewable Energy, 119(2018), $142-151$.

[7] Seraç, M.R., Aydın, S., Sayın, C. Comprehensive evaluation of performance, combustion, and emissions of soybean biodiesel blends and diesel fuel in a power generator diesel engine, Energy Sources, Part A: Recovery, Utilization, and Environmental Effects, 42(2020),18, 23162331.

[8] Özsezen AN, Çanakçi M., An investigation of the effect of methyl ester produced from waste frying oil on the performance and emi ssions of an idi diesel engine, J Facul Eng Architect Gazi Univ. 23(2008), 2, 395-404.

[10] Yaşar, F., Evaluation of Renewable Energy Source Algae as Biodiesel, Feedstock, European Journal of Technique (EJT), 9 (2019), 2, 298-311.

[11] Ozsezen, A.N., Canakci, M., Determination of performance and combustion characteristics of a diesel engine fueled with canola and waste palm oil methyl esters, Energy Conversion and Management, 52(2011), 1, 108-116.

[12] Ong, H.C. Masjuki, H.H., Mahlia, T.M.I., Silitonga, A.S., Chonga, W.T., Yusaf, T.,Engine performance and emissions using Jatropha curcas, Ceiba pentandra and Calophyllum inophyllum biodiesel in a CI diesel engine, Energy, 69 (2014), 427-445.

[13] Brunt, M.F.J., Rai, H., Emtage, A.L., The calculation of heat release energy from cylinder pressure data, SAE Technical Paper 1998: 981052.

[14] Hohenberg, GH., Advanced approaches for heat transfer calculations, SAE Technical Paper 1979: 790825.

[15] Checkel, M. and Dale, J., Computerized Knock Detection from Engine Pressure Records, SAE Technical Paper 1986: 860028. 
[16] Deverajan, Y., Munuswamy, D. B., \& Mahalingam, A., Influence of nano-additive on performance and emission characteristics of a diesel engine running on neat neem oil biodiesel, Environmental Science and Pollution Research, 25(2018), 1-6.

[17] İlkılıç, C., Çıl̆̆ın, E., \& Aydın, H., Terebinth oil for biodiesel production and its diesel engine application, Journal of the Energy Institute, 88 (2015), 292-303.

[18] Ç1lğın E., Investigation of biodiesel potential of new hybrid of Origanum Sp. Tekin-2017, native to Turkey, Fuel, 277(2020), 118180.

[19] Çelebi, Y., Aydın, H., Investigation of the effects of butanol addition on safflower biodiesel usage as fuel in a generator diesel engine, Fuel, 222(2018), 385-393.

[20] Singh, M., Anjum, F., Yadav, V., Sheikh, M.Y., Mathur, Y.B., Analysis of Combustion on Compression Ignition Diesel Engine fuelled with blends of Neem Biodiesel, International Research Journal of Engineering and Technology, 2017, 04.

[21] Anandavelu, K., Alagumurthi, N., \& Saravannan, C. G., Experimental investigation of using eucalyptus oil and diesel fuel blends in Kirloskar TV1 direct injection diesel engine, J Sustain Energy Environ, 2(2011), 3.

[22] Rajput RK. A textbook of automobile engineering. Laxmi; 2007.

[23] Heywood, J. Internal Combustion Engine Fundamentals. Macgraw-Hill Book Company, New York, 1988.

[24] Sayin, C., Gumus, M., and Canakci, M., Effect of fuel injection pressure on the injection, combustion and performance characteristics of a DI diesel engine fueled with canola oil me thyl esters-diesel fuel blends, Biomass and Bioenergy, 46(2012), 435-446.

[25] Oumer, A. N., Hasan, M. M., Baheta, A. T., Mamat, R., Abdullah, A. A., Bio-based liquid fuels as a source of renewable energy: A review. Renewable and Sustainable Energy Reviews, 88(2018), 82-98.

[26] Haik, Y., Selim, M.Y.E., Abdulrehman, T., Combustion of algae oil methyl ester in an indirect injection diesel engine, Energy, 36 (2011) 1827-1835.

[27] Kumar, A., Shukla, S. K., \& Tierkey, J. V., A review of research and policy on using different biodiesel oils as fuel for CI engine. Energy Procedia, 90(2016). 292-304.

[28] Lapuerta, M., Armas, O., Rodríguez-Fernández, J. Effects of biodiesel fuels on diesel engine emissions, Prog Energy Combust Sci, 34(2008), 198-223.

[29] Aydın, S. Detailed evaluation of combustion, performance and emissions of ethyl proxitol and methyl proxitol-safflower biodiesel blends in a power generator diesel engine, Fuel, 270 (2020), 117492. 